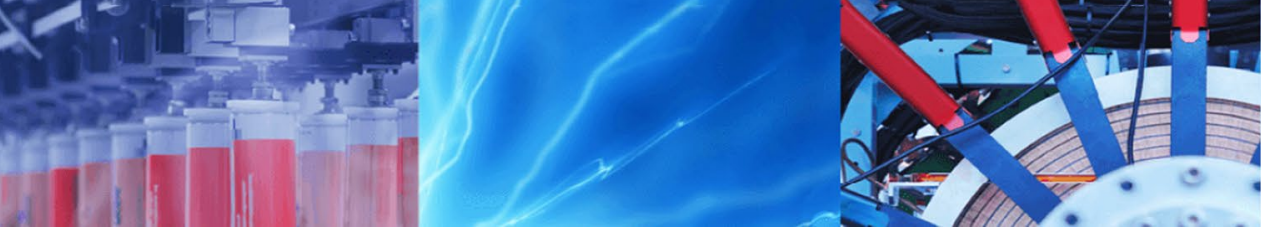

Research Article

\title{
Reliable energy prediction method for grid connected photovoltaic power plants situated in hot and dry climatic condition
}

\author{
Suprava Chakraborty ${ }^{1}$ D
}

Received: 5 November 2019 / Accepted: 28 January 2020 / Published online: 1 February 2020

(c) Springer Nature Switzerland AG 2020

\begin{abstract}
This paper presents a mathematical model to predict the energy generation of photovoltaic power plant in hot and humid climatic condition. This model is based on meteorological data and laboratory tested solar module parameters with twenty-four inputs and one output. In addition the twenty-four inputs drive an equation to calculate final energy generation from photovoltaic power plant. Validation of the proposed model was done by comparing the results of predicted energy generation using proposed model and PVWATT software model for two existing PV power plants of India. Monthly and annual energy production and errors will be the main criteria for the selection of batter model. The result shows that in comparison with PVWATT software proposed model was found to be more efficient and accurate to predict energy generation and proposed model also reduces mean absolute percentage error and root mean square error significantly compared to PVWATT software for hot and humid climatic condition.
\end{abstract}

Keywords Mathematical method $\cdot$ PV power plant $\cdot$ Energy generation $\cdot$ India $\cdot$ Climatic condition $\cdot$ Prediction model

\section{Introduction}

Accuracy of analytical models used for estimation of electrical energy production of photovoltaic power plants and systems is the key characteristic to determine tool expediency. Conventional analytical models are mathematical methods which use theoretical values indicated by solar panel manufacturer and estimated relations between energy production and meteorological input data in the surroundings of the production system [1, 2]. The outdoor performance of PV module is strongly dependent on local climate conditions including radiation, ambient temperature, humidity, Sun spectrum distribution and dust [3-8]. But the manufactures provide the parameters of PV modules only in the standard testing conditions (STC i.e. Irradiance $=1000 \mathrm{~W} / \mathrm{m}^{2}$, Temperature $=25^{\circ} \mathrm{C}$ and Air-mass $=1.5 \mathrm{G}$ ) i.e. based on indoor testing of solar PV modules. Parameters of PV modules at STC do not imitate its performance in outdoor field conditions. These assumptions are cases, error in estimation from the modelled values and specific annual energy production can drop significantly. Thus, correct PV module selection and accurate prediction of energy output from PV module is solely dependent on reliable knowledge and understanding of the PV module performance under different operating conditions.

Using estimated global irradiance [9-17], rough estimation of the average energy production of the PV power plants is possible. Coelho and Castro [18] developed Irradiance and power output prediction models to predict energy production of the PV power plants. Estimation of solar irradiance is an important step in prediction of energy generation from solar PV modules but is not the only step. Other parameters are also associated in the prediction of energy generation from PV plants. Celik and Acikgoz [19] developed five-parameters based model

Suprava Chakraborty, suprava1008@gmail.com | ${ }^{1}$ Madanapalle Institute of Technology and Science, Angallu, Chittoor District, Madanapalle, Andhra Pradesh 517325, India. 
to predict average energy production of the PV power plants. Form the literature survey it was observed that significantly lesser number of literatures is available to predict the field performance of PV power plant $[8,20]$. The average performance of a PV system under variable climatic-conditions can be predicted through some power efficiency models [19, 21-25]. Neural networks model is more complicated one which is based on trial and error processes and requires past experience for successful implementation $[26,27]$. Most of the above mentioned models are based on theoretical values, perennial average meteorological data and statically assumptions values [28]. These limitations of the mentioned literatures are barrier in easy prediction of energy generation from PV power plants. There are three most popular commercial software tools available to predict the energy generation of PV power plants such as PVsyst, RetScreen and PVWATT. These softwares are also using same set of data which is used by conventional aforesaid energy prediction model. The main task of this research is to take results of the conventional analytical model from the actual measured input data for a specific location and compare them newly developed field performance based prediction model with the real measured energy production. Then only one can trust the results of new prediction model and can use results for commercial implementation purpose.

Among these three tools PVWATT is of acceptable accuracy level one and less complicated, therefore this paper is comparing the predicted energy generation using proposed method and PVWATT with practical energy generation of the PV plants installed in hot and dry climate of India.

The objective of this paper is to present a simple but accurate and reliable mathematic method to estimate the energy generation of PV power plant in hot and dry climatic condition. This method is applicable to choose the best suited PV technology for hot and dry climatic conditions.

Finding of this paper will help in energy supply planning to make the energy generation economic and environment friendly. This paper is also showing a comparative study of two different PV technologies in same climatic condition which is concluding which technology is practically performing better in hot and dry climatic condition. This study is first time in the hot \& dry climatic condition.

In five stages the research is presented here [29]. In Sect. 1 initially explained environmental effect on photovoltaic technology are presented followed by the brief literature survey of research work. Thereafter, the problems which are facing related to photovoltaic power industry were discussed. Finally, the objectives of the present work are highlighted. In Sect. 2, instruments, data and places where from the practical data are collected are explained in order to understand the research work is clearly. Detail of Experimental Set-ups and method of determine temperature co-efficient and NOCT value for different PV technologies through experiment are also clearly discussed in Sect. 2.1. Section 2.2 presents the selection of PV plants for validation of proposed model. The method of collecting meteorological data and experimentally procedure of calculating module related data are logically explained in Sect. 3. Section 3.1, presents the development of mathematical model to predict the energy generation. In Sect. 4 analyses of real-time energy generation data of the year 2014 for two existing PV power plants of India based on different PV technology is presented. Validation of the mathematical model and comparison with predicted generation from PVWATT is also presented. Section 4.1, presents the collected data of solar PV project in India and Sect. 4.2 deals with the validation of the proposed model. In Sect. 5 based on proposed mathematical model best suited PV technology is selected for hot and dry climatic zone of India. Section 6 concludes that the prediction of energy generation using proposed model in hot and dry climatic condition is less erroneous than PVWATT.

\section{Places, instruments and data}

Correct PV module selection and accurate prediction of energy output from PV module is solely dependent on reliable knowledge and understanding of the PV module performance under different operating conditions. Therefore to minimized error following experiments are performed to determine PV module related input parameter.

\subsection{Detail of experimental set-ups}

\subsubsection{QuickSun 700A large area solar simulator}

QuickSun 700A is capable of measuring the I-V characteristics of $2 \mathrm{~m} \times 2 \mathrm{~m}$ sized photovoltaic modules whether they are made of thin film or crystalline material it is effective and reliable both in production and quality control application. Experimental set up of QuickSun 700A sun simulator is shown in Figs. 1 and 2.

\subsubsection{Environmental test chamber}

Environmental chamber, BSC-ETC 1000 manufactured by Ballice System and Controls Pvt. Ltd. of working space $1.2 \mathrm{~m} \times 1.2 \mathrm{~m} \times 1.2 \mathrm{~m}$, is used to provide field condition to a module. In this chamber temperature and humidity can be applied as per requirement of the user. But no light source is available in this chamber. 


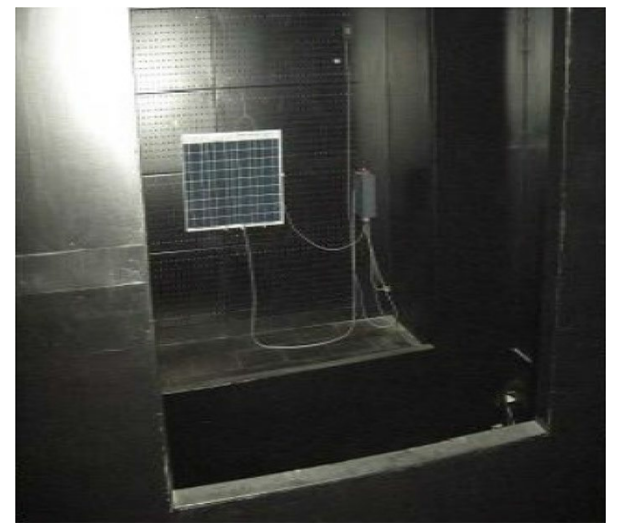

Fig. 1 PV module placed in QuickSun 700A large area solar simulator chamber for testing purpose

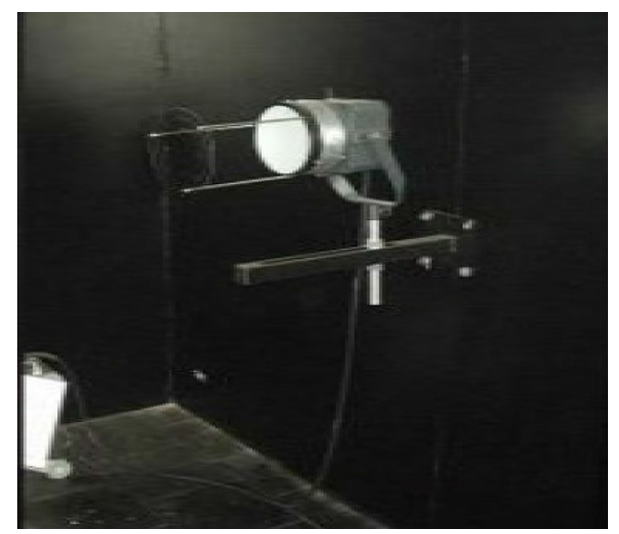

Fig. 2 Xenon Lamp of QuickSun 700A large area solar simulator

Figures 3 and 4 depicts the environmental test chamber and NOCT correction factor respectively.

\subsubsection{Nominal operating cell temperature (NOCT) test bed}

NOCT test set up is arranged as per IEC17025. An open rack is installed to support the test module and pyranometer in the specified manner as shown in Figs. 5 and 6. The open is tilted at $45^{\circ} \pm 5^{\circ}$ to the horizontal with the front side pointed toward the equator. A pyranometer, mounted in the plane of the module and within $0.3 \mathrm{~m}$ of the test array. Instruments to measure wind speed down to $0.25 \mathrm{~m} \mathrm{~s}^{-1}$ and wind direction, installed approximately $0.7 \mathrm{~m}$ above the top of the module and $1.2 \mathrm{~m}$ to the east or west. An ambient temperature sensor, with a time constant equal to or less than that of the module, installed in a shaded enclosure with good ventilation near the wind sensors. For measurement purpose cell temperature sensors, attached by solder or thermally conductive adhesive to the backs of two solar cells near the middle of each test module are

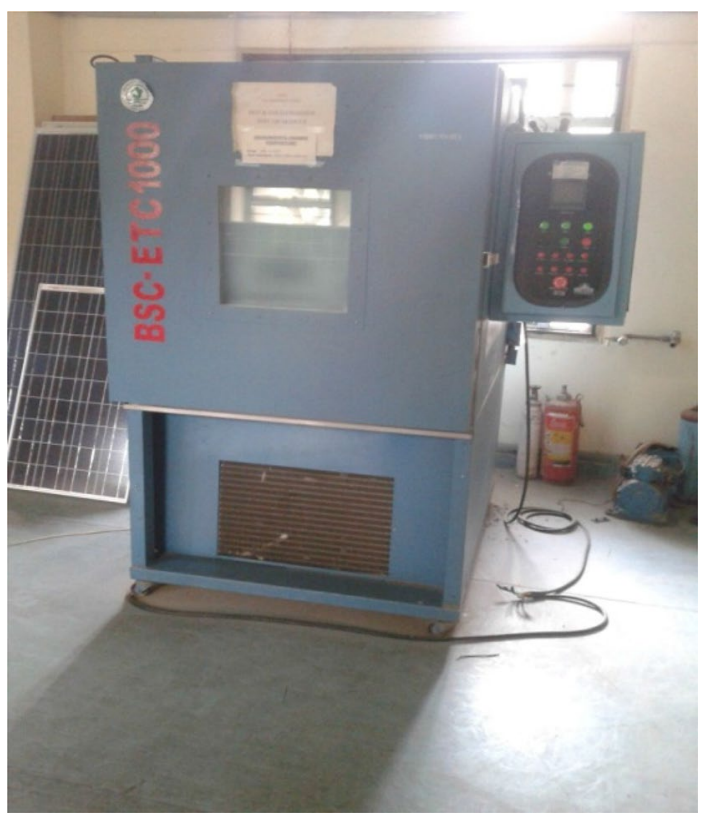

Fig. 3 Environmental test chamber

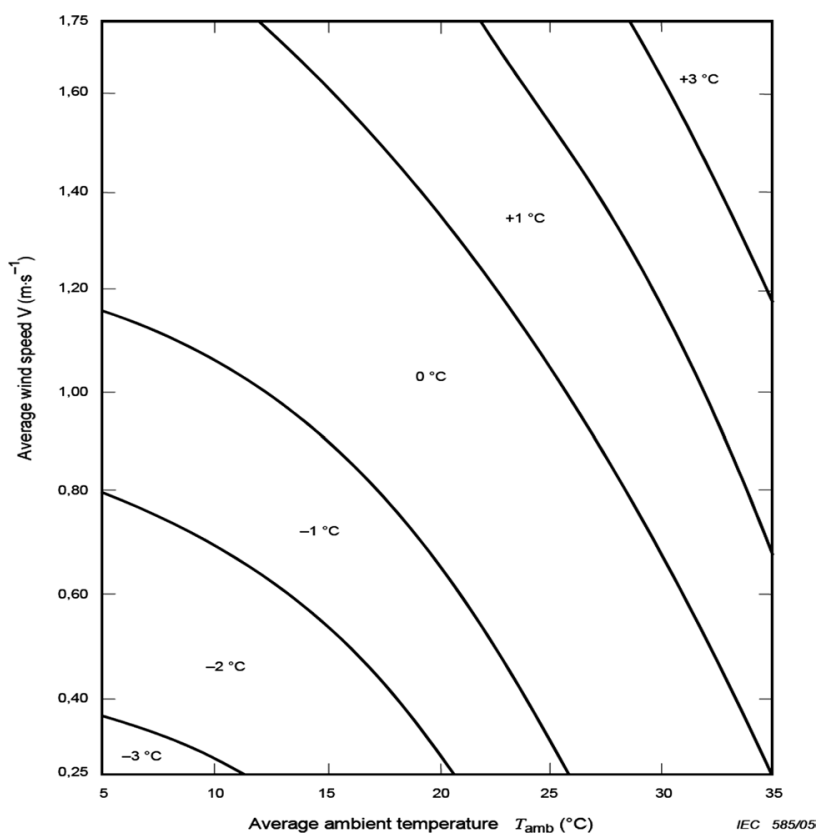

Fig. 4 NOCT correction factor [IEC 61646]

placed. A data acquisition system made by National Instrument with temperature measurement accuracy of $\pm 1{ }^{\circ} \mathrm{C}$ to record the Irradiance, ambient temperature, cell temperature, wind speed, wind direction within an interval of $1 \mathrm{~s}$ is installed. The data acquisition system record per $1 \mathrm{~min}$ average of those 60 data points.

Determination of NOCT is performed as per IEC 61215. NOCT is defined as the equilibrium mean solar cell junction 


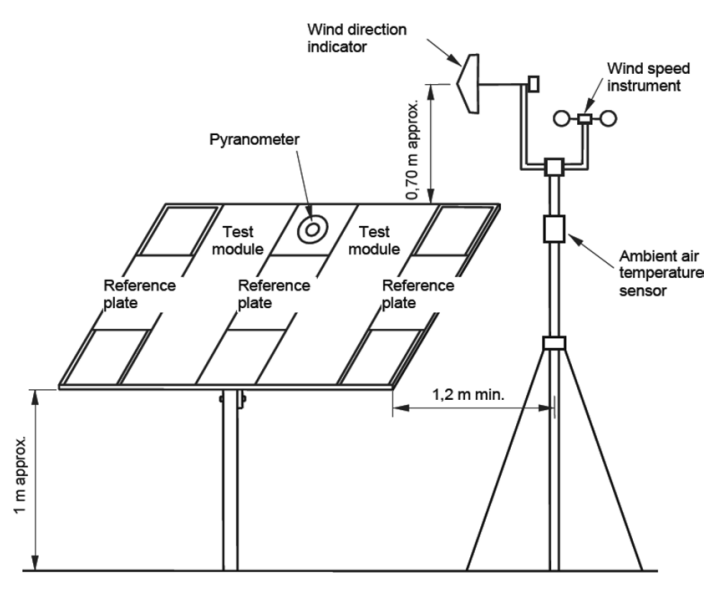

Fig. 5 Schematic diagram of NOCT set-up

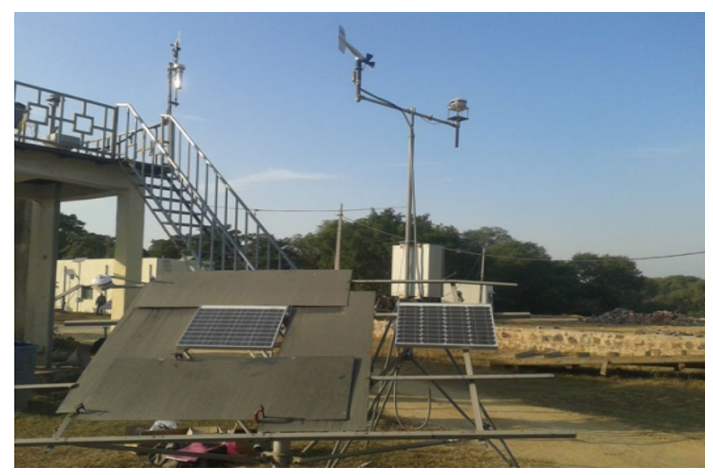

Fig. 6 NOCT test bed at SEC

temperature within an open-rack mounted module in the following standard reference environment (SRE) i.e. Tilt angle: $45^{\circ}$ from the horizontal, Total irradiance: $800 \mathrm{~W} \mathrm{~m}^{-2}$, Ambient temperature: $20^{\circ} \mathrm{C}$, Wind speed: $1 \mathrm{~m} \mathrm{~s}^{-1}$, Electrical load: nil (open circuit).

\subsubsection{Determination of temperature co-efficient of power}

Temperature co-efficient of power for two PV modules named SS-150 and FS-377 are determined as per IEC 61215 and IEC 61646 respectively. With increase of temperature variation in power output is tabulated in Table 1. For this experiment Environmental Test Chamber and Sun-Simulator is used. In environmental chamber modules are heated and their power output is studied using Sun-Simulator. The experiment was started at $25^{\circ} \mathrm{C}$ and readings were taken at an interval of $5^{\circ} \mathrm{C}$ till the temperature of $\mathrm{PV}$ modules reached to $70^{\circ} \mathrm{C}$.

In Fig. 7, curve 1 and curve 2 represents the variation of power output with respect to temperature for PV
Table 1 Temperature co-efficient of power determination

\begin{tabular}{lll}
\hline $\begin{array}{l}\text { Temperature of PV mod- } \\
\text { ule }\left({ }^{\circ} \mathrm{C}\right)\end{array}$ & $\mathrm{P}_{0}$ multi C-Si $(\mathrm{W})$ & $\mathrm{P}_{0} \mathrm{CdTe}(\mathrm{W})$ \\
\hline 25 & 140 & 68 \\
30 & 137.5 & 67.8 \\
35 & 135.5 & 67.6 \\
40 & 131.5 & 67.1 \\
45 & 127.5 & 66.7 \\
50 & 125 & 66.2 \\
55 & 123 & 65.6 \\
60 & 119.5 & 64.4 \\
65 & 115.5 & 63.5 \\
70 & 112 & 62.7 \\
\hline
\end{tabular}

module SS-150 and FS-377 respectively. Slopes of the curves are divided by their STC condition power output and then converted that in percentage to get the temperature co-efficient of power. Calculated temperature co-efficients of power are shown in Table 2.

\subsubsection{Measurement of nominal operating cell temperature (NOCT)}

Experimental data collected for calculation of NOCT of SS-150 and FS-377 are presented in Table 3. Tilted Radiation i.e. global solar irradiance at a tilt angle of $45^{\circ}$ with horizontal as required in NOCT setup (Specified in IEC 61215), air temperature, temperatures of PV modules, wind direction and wind speed are collected from NOCT test set up, presented in Table 3, and analysed to calculate NOCT value of the PV modules.

In Fig. 8 temperature difference versus Irradiance curve of the selected PV modules are shown. Curve 1 and curve 2 represents the NOCT calculation curves for SS-150 and FS-377 PV modules.

For SS-150 PV module

From graph for $800 \mathrm{~W} / \mathrm{m}^{2}$ radiation $\mathrm{T}_{\mathrm{m}}-\mathrm{T}_{\mathrm{amb}}=28^{\circ} \mathrm{C}$

$T_{m}$ is the temperature of PV module and $T_{a m b}$ is ambient temperature of $\mathrm{PV}$ module.

Preliminary value of NOCT $=(28+20)^{\circ} \mathrm{C}=48^{\circ} \mathrm{C}$

Correction factor $=-1{ }^{\circ} \mathrm{C}$ (From Fig. 3)

$\mathrm{NOCT}=48-1{ }^{\circ} \mathrm{C}=47^{\circ} \mathrm{C}$

NOCT value of SS- 150 is $47^{\circ} \mathrm{C}$.

For FS-377 PV module

From graph for $800 \mathrm{~W} / \mathrm{m}^{2}$ radiation $\mathrm{T}_{\mathrm{m}}-\mathrm{T}_{\mathrm{amb}}=26^{\circ} \mathrm{C}$

Preliminary value of NOCT $=(26+20){ }^{\circ} \mathrm{C}=46{ }^{\circ} \mathrm{C}$

Correction factor $=-1{ }^{\circ} \mathrm{C}$ (From Fig. 3)

$\mathrm{NOCT}=46-1{ }^{\circ} \mathrm{C}=45^{\circ} \mathrm{C}$

NOCT value of FS-377 is $45^{\circ} \mathrm{C}$. 
Fig. 7 Temperature co-efficient of power of multi $\mathrm{C}-\mathrm{Si}$ and CdTe module

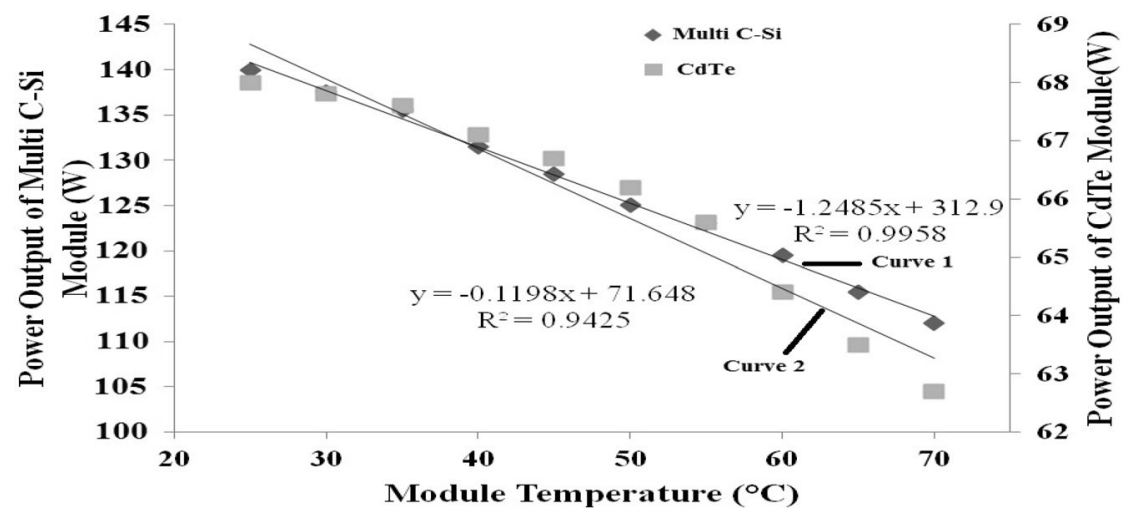

Table 2 Temperature co-efficient of the PV modules

\begin{tabular}{ll}
\hline PV module & $\begin{array}{l}\text { Temperature } \\
\text { co-efficient of } \\
\text { power }\end{array}$ \\
\hline SS-150 & $0.43 \% /{ }^{\circ} \mathrm{C}$ \\
FS-377 & $0.25 \% /{ }^{\circ} \mathrm{C}$ \\
\hline
\end{tabular}

and Kathoti village of Nagaur district in Rajasthan respectively as shown in Fig. 9.

Specifications of the PV modules used in those PV plants are enlisted in Table 4. But due limitation in size of environmental chamber multi C-Si module of capacity $150 \mathrm{~W}_{\mathrm{p}}$ (SS-150) is selected for experimental purpose from

\subsection{Selection of PV plants for validation of proposed model}

To validate the newly developed mathematical model some meteorological and PV module related parameters are need to be collected. Two PV power plants of different PV technologies situated in same district of Rajasthan lies in hot and dry climatic zone are selected for validation of the proposed model. One PV plant is based on Multi C-Si PV modules, another one of CdTe technology. Selected multi C-Si and CdTe based PV plants are situated at Bhojas

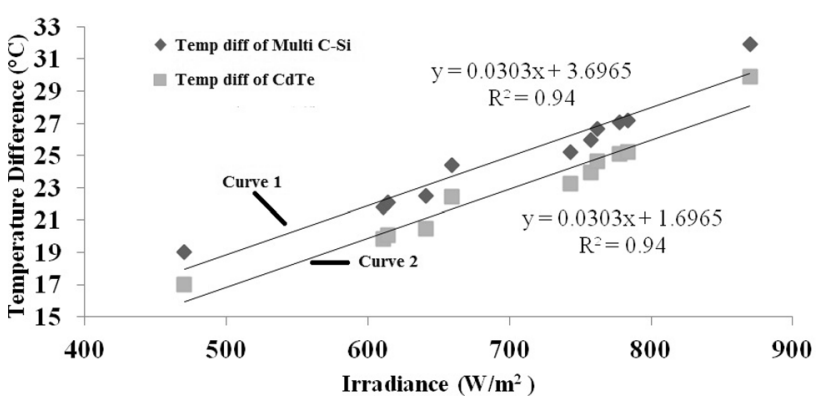

Fig. 8 Temperature difference $\left(T_{m}-T_{a m b}\right.$ versus irradiance

Table 3 NOCT determination data collection

\begin{tabular}{|c|c|c|c|c|c|c|c|}
\hline Tilt radiation $\left(\mathrm{W} / \mathrm{m}^{2}\right)$ & $\begin{array}{l}\text { Air tempera- } \\
\text { ture }\left({ }^{\circ} \mathrm{C}\right)\end{array}$ & $\begin{array}{l}\text { Multi C-Si module } \\
\text { temperature }\left({ }^{\circ} \mathrm{C}\right)\end{array}$ & $\mathrm{T}_{\text {diff }}\left({ }^{\circ} \mathrm{C}\right)$ & $\begin{array}{l}\text { CdTe module } \\
\text { temperature }\left({ }^{\circ} \mathrm{C}\right)\end{array}$ & $\mathrm{T}_{\text {diff }}\left({ }^{\circ} \mathrm{C}\right)$ & Wind direction $\left({ }^{\circ}\right)$ & $\begin{array}{l}\text { Wind } \\
\text { speed } \\
(\mathrm{m} / \mathrm{s})\end{array}$ \\
\hline 610.5 & 19.03 & 40.86 & 21.83 & 38.86 & 19.83 & 239.78 & 0.27 \\
\hline 613.83 & 19.2 & 41.28 & 22.08 & 39.28 & 20.08 & 244.71 & 0.17 \\
\hline 659.51 & 19.92 & 44.35 & 24.43 & 42.35 & 22.43 & 270.35 & 0.77 \\
\hline 742.86 & 20.79 & 46.01 & 25.22 & 44.01 & 23.22 & 271.18 & 1.25 \\
\hline 757.46 & 22.66 & 48.61 & 25.95 & 46.61 & 23.95 & 295.53 & 1.1 \\
\hline 762.18 & 21.43 & 48.07 & 26.64 & 46.07 & 24.64 & 288.97 & 1.2 \\
\hline 777.78 & 22.24 & 49.31 & 27.07 & 47.31 & 25.07 & 280.16 & 0.75 \\
\hline 783.38 & 22.05 & 49.25 & 27.2 & 47.25 & 25.2 & 290.9 & 0.98 \\
\hline 869.93 & 24.72 & 56.63 & 31.91 & 54.63 & 29.91 & 276.64 & 0.27 \\
\hline 640.59 & 27.08 & 49.55 & 22.47 & 47.55 & 20.47 & 112.49 & 0.6 \\
\hline 470.24 & 25.55 & 44.56 & 19.01 & 42.56 & 17.01 & 51.06 & 1.63 \\
\hline Average $=22.24$ & & & & & & Average $=0.82$ & \\
\hline
\end{tabular}


Fig. 9 Bhojas and Kathoti village of Nagaur district in Rajasthan

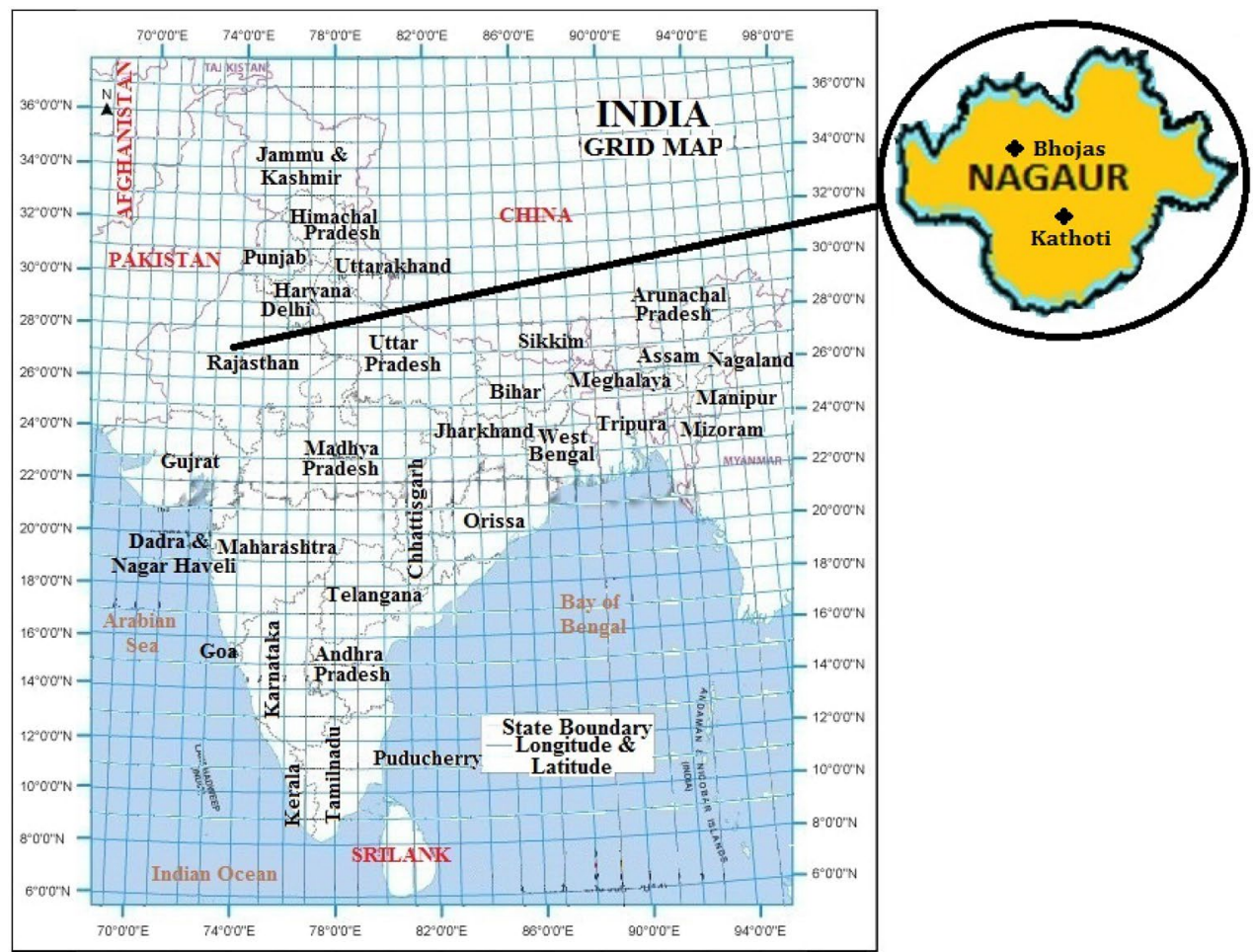

Table 4 Technical specifications of PV modules used in the chosen PV plants

\begin{tabular}{lllc}
\hline PV cell type & Manufacturer name & Model no & $\mathrm{P}_{\text {STC }}(\mathrm{W})$ \\
\hline Multi C-Si & Solar Semiconductor Pvt. Ltd. & SS-300 & 300 \\
CdTe & First solar & FS-377 & 70 \\
\hline
\end{tabular}

same manufacturer though the actual modules installed in the plant are of $300 \mathrm{~W}_{\mathrm{p}}$.

Required module parameters such as Nominal Operating Cell Temperature (NOCT) and temperature co-efficient of Power $\left(\gamma_{p}\right)$ of SS-150 and FS-377 are experimentally performed at Photovoltaic Test Facility Laboratory of National Institute of Solar Energy (NISE), Ministry of New and Renewable Energy (MNRE), India. National Institute of Solar Energy (NISE), formerly known as Solar Energy Centre (SEC) is an autonomous body has established high precision facilities for testing PV modules under indoor laboratory conditions. This is the first laboratory in India to acquire accreditation for testing PV modules as per NABL quality system. The laboratory has established quality system as per IEC17025, for qualification testing of PV modules as per IEC61215 or IEC 61646 standards.

\section{Methodology developed}

Methodology used in this work consists of following steps. Figure 10 represents the algorithms of research work done in this paper.

1. Development of simple mathematical model to predict the energy generation form PV power plants. To developed the mathematical model two major step were performed

(a) Experimentally determination of the PV module related input parameter needed to prepare the proposed mathematical model.

(b) Twenty-four input metrological parameters are analysed for hot and dry climatic location and drive an equation to calculate final energy generation from photovoltaic power plant.

2. Selection of PV power plants under NTPC Vidyut Vyapar Nigam Limited (NVVN) scheme to validate the mathematical model. Actual Energy generation data of each month for the entire year of 2014 was collected from data logger.

3. For the same plants energy generation is calculated using the online PVWATT software that is considered as reliable software in energy prediction of solar PV plants.

4. Prediction of energy generation using proposed mathematical model. 
Fig. 10 Simplified sketch of methodology used in the work

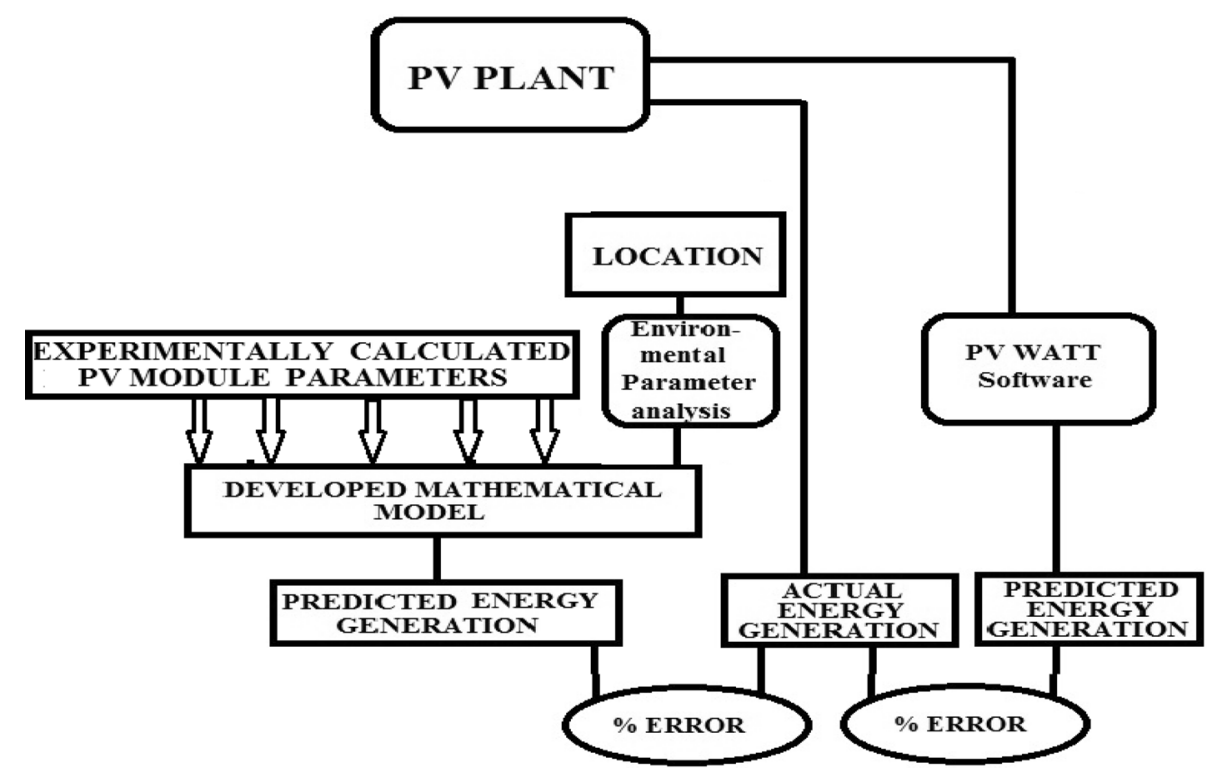

5. Comparison of actual energy generation with (3) and (4) and calculation of error to conclude which model is best to predict PV plant energy generation in hot and humid climatic condition.

\subsection{Preparation of mathematical model to predict the energy generation}

Output of PV module is dependent on the module parameters and meteorological parameters, mainly on insolation and ambient temperature. Proposed Mathematical Model

\subsubsection{Solar radiation on tilted PV array}

In NREL website the long-term published data of solar radiation and other meteorological parameters are available as hourly average values on horizontal surface for different grid points of India. The solar radiation on a tilted PV array is the main input parameter for the design of the PV system. According to the Liu and Jordan formula using the hourly beam and diffuse radiation on a horizontal surface, the total radiation on a tilted PV array (at angle $\beta$ ) for a given latitude $\varphi$ can be evaluated:

$$
\begin{aligned}
I_{t}= & I_{d r} \frac{(\operatorname{Cos} \phi \operatorname{Cos} \beta+\operatorname{Sin} \phi \operatorname{Sin} \beta \operatorname{Cos} \gamma) \operatorname{Cos} \delta \operatorname{Cos} \omega+\operatorname{Cos} \delta \operatorname{Sin} \omega \operatorname{Sin} \beta \operatorname{Sin} \gamma+(\operatorname{Sin} \phi \operatorname{Cos} \beta-\operatorname{Cos} \phi \operatorname{Sin} \beta \operatorname{Cos} \gamma) \operatorname{Sin} \delta}{\operatorname{Cos} \phi \operatorname{Cos} \delta \operatorname{Cos} \omega+\operatorname{Sin} \phi \operatorname{Sin} \delta} \\
& +I_{d f} \frac{1+\operatorname{Cos} \beta}{2}+\rho \frac{1-\operatorname{Cos} \beta}{2}\left(I_{d r}+I_{d f}\right)
\end{aligned}
$$

is developed to determine the energy generation of fixed PV modules based PV power plant. Stepwise development of the proposed model is represented below:

\subsubsection{Development of prediction model}

Accuracy of proposed energy prediction model critically depend on accurate meteorological input parameters and equation to calculate final energy generation from photovoltaic power plant. The details meteorological analyses are as follows.
$I_{d r}$ Hourly beam radiation on a horizontal surface, $I_{d f}$ Hourly diffuse radiation on a horizontal surface, $\rho$ is the reflection coefficient of the ground $(0.2$ and 0.6 for non-snow-covered and snow-covered ground, respectively), $\theta_{i}$ is angle of incidence, $\theta_{z}$ zenith angle, $\phi$ Latitude Angle, $\beta$ Tilt Angle, $\gamma$ Azimuth Angle, $\delta$ Solar Declination Angle, $\omega$ Hour Angle.

Insolation on tilted surface, $I_{T L T}=\int_{S_{R}}^{S_{S}} I_{t}$

$S_{R}$ Sunrise time, $S_{S}$ Sunset time.

Daily PV array output is the summation of the hourly energy output. 


\subsubsection{Equivalent full sun-shine hours on tilted surface}

No of hours for which the intensity of solar radiation incident at a place is kept constant at its peak value of $1 \mathrm{~kW} / \mathrm{m}^{2}$ is known as equivalent hours of full sunshine $\left(h_{e t}\right)$. When insolation on tilted unit area surface is expressed by $I_{T L T} \mathrm{kWh} /$ $\mathrm{m}^{2} /$ day, then it can be expressed as constant peak value of solar radiation of $1 \mathrm{~kW} / \mathrm{m}^{2}$ incident on a receiving surface for $I_{T L T} h$, then $h_{e t}$ will be equal to $I_{T L T} \mathrm{~h} /$ day. The expression is given by Eq. (3)

$h_{e t}=\frac{I_{T L T}}{1 \mathrm{~kW} / \mathrm{m}^{2}}$

$h_{e t}$ is Equivalent full sun-shine hours on tilted surface, $I_{\text {TLT }}$ is Insolation on tilted surface in $\mathrm{kWh} / \mathrm{m}^{2} /$ day.

\subsubsection{PV panel output after temperature correction}

The output of PV module is dependent on solar radiation and the operating temperature of PV module. Rise in the PV operating temperature with respect to STC condition, reduces the energy output from PV module. Operating temperature of PV module can be calculated by means of ambient temperature, incident solar irradiance on PV module at given location and Nominal Operating Cell Temperature (NOCT) of the particular technology.
$P_{\text {otc }}=P_{\text {STC }}\left[1-\left\{T_{\text {amb }}+\left(\frac{(N O C T-20)}{800} \times I_{t}\right)-T_{\text {STC }}\right\} \times \gamma_{P}\right]$

$P_{\text {otc }}$ is Panel output after temperature correction, $P_{S T C}$ is Power output at STC, $T_{a m b}$ is ambient Temperature in ${ }^{\circ} \mathrm{C} . N O C T$ is Nominal Operating Cell Temperature, $l_{t}$ is Irradiance in $\mathrm{W} / \mathrm{m}^{2}, T_{\text {STC }}$ is the temperature of the PV module at STC in ${ }^{\circ} \mathrm{C}, \gamma_{P}$ is Temperature coefficient of Power for PV panel in $\% /{ }^{\circ} \mathrm{C}$.

\subsubsection{Electrical energy generated from PV plant}

$E_{P V P}=\sum_{N=1}^{d} N \times P_{o t c} \times h_{e t} \times\left(1-d_{f}\right)\left(1-h_{f}\right)\left(1-w_{l}\right)\left(1-m_{l}\right) \times \eta_{\text {inv }}$

$E_{P V P}$ is Energy output from PV plant, $d_{f}$ is dust factor in \%, $h_{f}$ is humidity factor in $\%, w_{l}$ is Wiring losses in $\%, m_{l}$ is Mismatch losses in $\%, \eta_{i n v}$ is inverter efficiency in $\%, d$ is the no of days the PV plant is operating. Equation (5) is the final model equation to predict the power output from PV module.

Figure 11 presents the simplified view of the proposed mathematical model for prediction of energy generation from PV power plant. All the input parameters are clearly indicated in left hand side of the figure and stepwise calculation is also very clear. Output of the model is energy generation from PV power plant. Accuracy of the proposed
Fig. 11 Simplified view of energy predict model for PV power plants

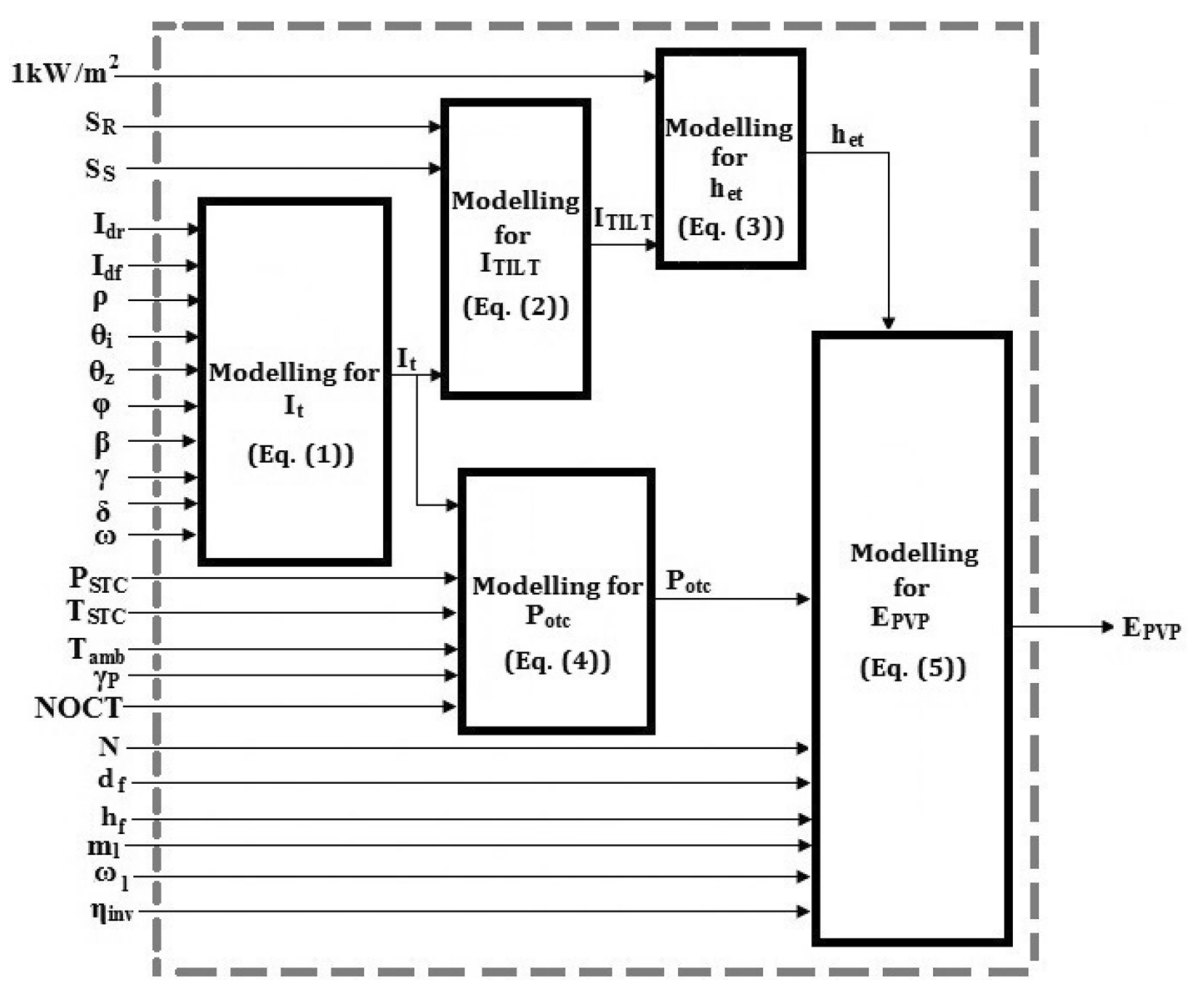


energy prediction model is dependent on the correctness of the input parameters.

\section{Results}

\subsection{Collected data of solar PV projects in India}

Under the scheme of Jawaharlal Nehru National Solar Mission (JNNSM) numbers of Solar PV plants are already installed in India and many other are going to be installed to fulfil the target of JNNSM. For validation of the proposed model, monthly generation data for the entire year of 2014 were collected from NTPC Vidyut Vyapar Nigam Ltd (NVVN) [30] for two grid interactive PV plants of same size (5 MW) based on two different PV technologies in same district (Naguar) of Rajasthan. Grid integrated Multi C-Si and CdTe PV plants were installed by DDE Renewable Energy Limited and Azure Power (Rajasthan) Private Limited (APRPL) respectively. Multi $\mathrm{C}-\mathrm{Si}$ based PV plant is situated in Bhojas village whereas $\mathrm{CdTe}$ technology based plant is installed in Kathoti village. Being very near to each other meteorological parameters are almost same for these two locations and are in hot and dry climatic zone. In both the PV plants, PV panels are installed at a fixed tilt angle of $27^{\circ}$ i.e. latitude angle of that location. Meteorological parameter of Naguar district required as input parameter of the proposed model are tabulated in Table 5 . Hourly data of meteorological parameters are collected from Typical Meteorological Year (TMY) file from NREL website.

Table 5 shows that maximum Global Horizontal Insolation (GHI) of $7.22 \mathrm{kWh} / \mathrm{m}^{2} /$ day is observed in the month of May and minimum is found in the month of January with value of $4.15 \mathrm{kWh} / \mathrm{m}^{2} /$ day. Temperature in that location varies from 16.18 to $37.46^{\circ} \mathrm{C}$. Other related insolation parameters such as Direct Normal Insolation (DNI) and Diffuse Horizontal Insolation (DHI) are also presented to calculate insolation at $27^{\circ}$ tilted panel.

Tilted insolation is calculated using Eq. (1). Figure 12 shows the pattern of tilted $\mathrm{GHI}$ and day-time temperature is similar for the concerned site.

Other required meteorological parameters are collected from National Aeronautics and Space Administration (NASA) renewable energy resource website (Surface Meteorology and Solar Energy). Other two major
Table 5 Meteorological parameter analysis

\begin{tabular}{lllll}
\hline Month & Avg GHI (kWh) & Avg DNI (kWh) & Avg DHI (kWh) & $\begin{array}{l}\text { Avg ambient } \\
\text { temperature } \\
\left({ }^{\circ} \mathrm{C}\right)\end{array}$ \\
\hline January & 4.15 & 5.50 & 1.42 & 16.18 \\
February & 4.67 & 4.03 & 2.2 & 19.83 \\
March & 6.27 & 6.35 & 2.02 & 26.74 \\
April & 6.80 & 5.33 & 2.81 & 32.92 \\
May & 7.22 & 5.16 & 3.141 & 37.46 \\
June & 6.55 & 4.13 & 3.21 & 35.37 \\
July & 5.85 & 3.30 & 3.17 & 33.04 \\
August & 5.77 & 3.96 & 2.71 & 28.69 \\
September & 5.83 & 4.99 & 2.31 & 28.94 \\
October & 5.37 & 5.66 & 1.84 & 27.86 \\
November & 4.62 & 5.99 & 1.4 & 22.59 \\
December & 3.87 & 4.46 & 1.61 & 18.22 \\
\hline
\end{tabular}

Fig. 12 Meterorological parameter of the location

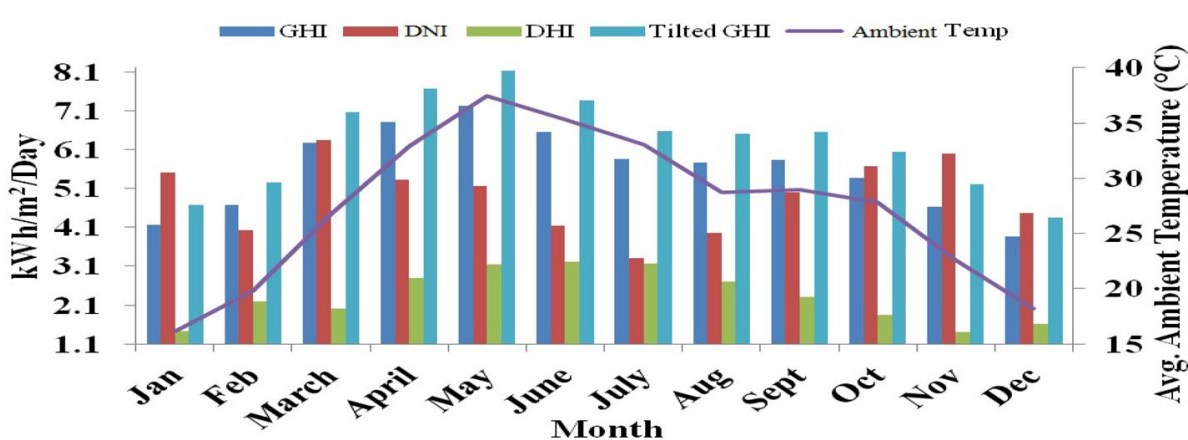

SN Applied Sciences 
Fig. 13 Clearness index and humidity of Nagaur district of Rajasthan

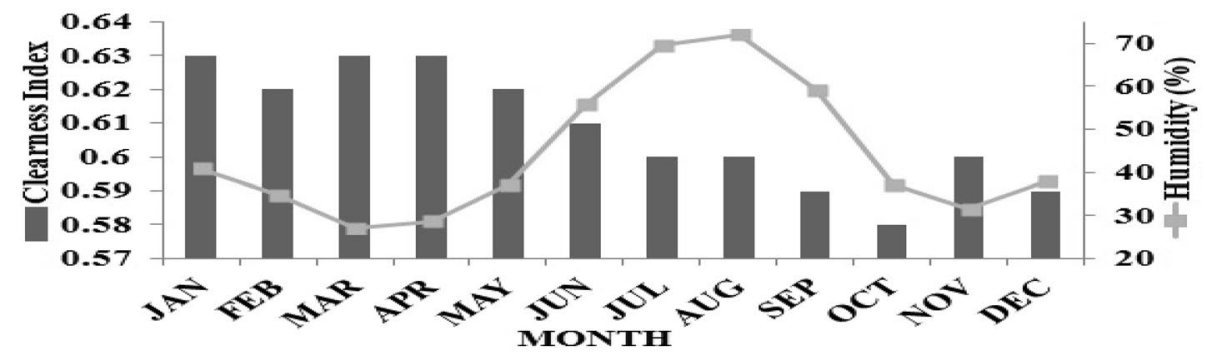

meteorological parameters such as clearness index which indicate the pollution and dust of that location and humidity are presented in Fig. 13. Annual average clearness index and humidity of that location is 0.61 and $44.4 \%$ respectively. Minimum clearness index is observed in the month of October with a value of 0.58 and maximum humidity is found in the month of August with a value of $72 \%$.

\subsection{Prediction of energy generation using PVWATT software and proposed mathematical model}

Using Eq. (5) monthly predicted energy generation of Multi C-Si and CdTe PV plant are calculated through the proposed model. Reference value of some parameters such as $d_{f}, h_{f}, w_{l}, m_{l}$ and $\eta_{i n v}$ are collected from the National Renewable Energy Laboratory (NREL) [31]. For the particular location $d_{f}$ and $h_{f}$ are considered as $2 \%$ as it's located in hot and dry climate condition. In hot and dry climatic condition the effect of humidity and dust is relatively less. The value of $w_{l}, m_{l}$ and $\eta_{\text {inv }}$ have been considered as $1.5 \%, 1.25 \%$ and $95 \%$ respectively. For the same PV plants monthly energy generation are calculated through PVWATT software. Then results from proposed model and PVWATT are compared with the actual monthly energy generation of the PV plants to know which one is giving better results. Figure 14a and $b$ indicates comparison of actual energy generation for CdTe PV and Multi C-Si PV technology power plant with proposed model and PV WATT software.

Figures $15 a, b$ and $16 a, b$ are showing the regression coefficient of energy generation predicted from proposed model, PVWATT with actual energy generation for Multi C-Si based and CdTe based PV power plants.

Percentage errors in the prediction of monthly energy generation from proposed model and PVWATT for Multi C-Si and CdTe PV plants are presented in Table 6.

All types of error coefficients value such as Root Mean Square Error (RMSE), Normalized root mean square error,
Fig. 14 Comparison of energy generation for a CdTe, $\mathbf{b}$ multi C-Si PV plant

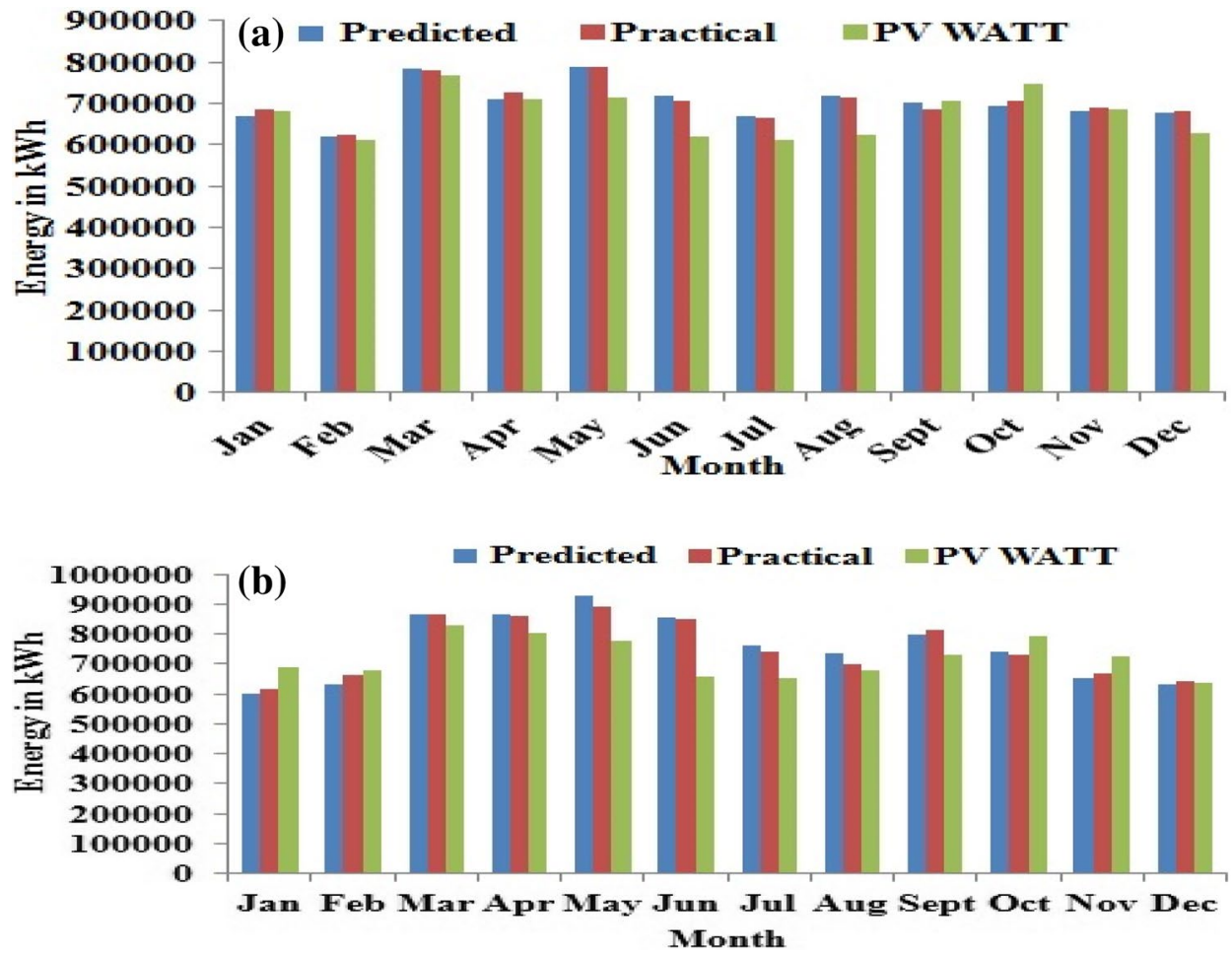



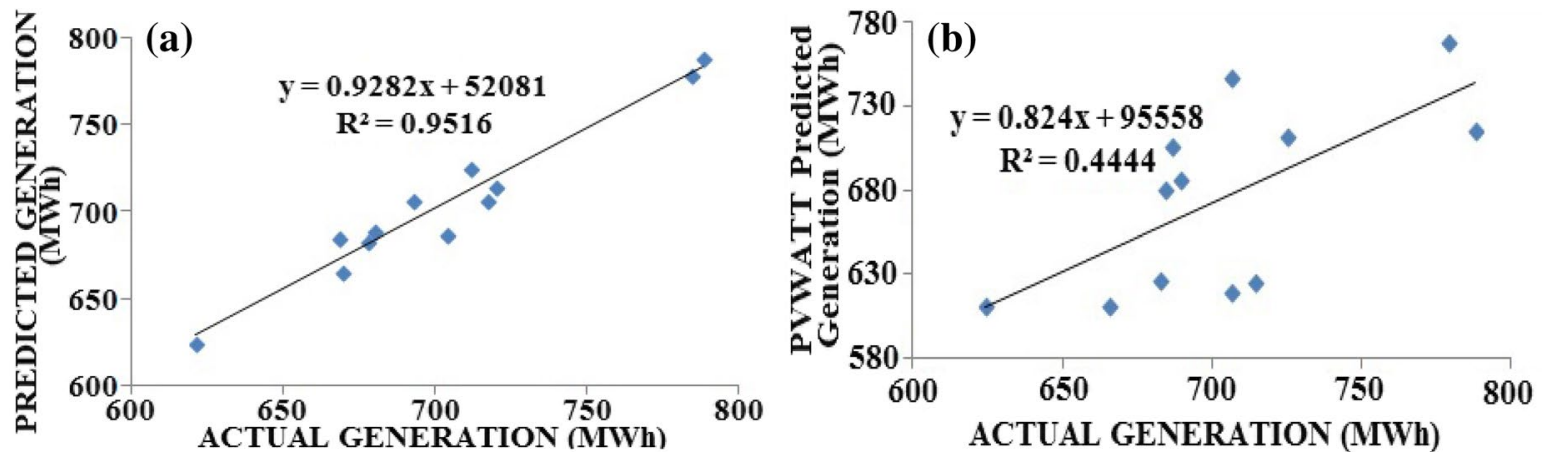

Fig. 15 Regression between a proposed model, b PV WATT predicted generation and actual multi C-Si based power plant generation

Fig. 16 Regression between predicted generation using a proposed model, b PV WATT and actual CdTe based power plant generation
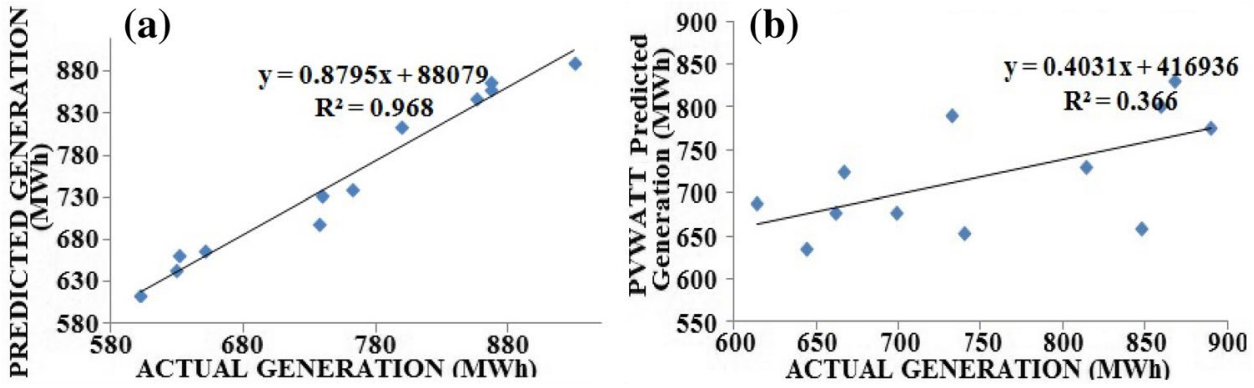

Table 6 The percentage error calculation of the proposed model and PVWATT

\begin{tabular}{|c|c|c|c|c|}
\hline \multirow[t]{2}{*}{ Month } & \multicolumn{2}{|c|}{$\begin{array}{l}\text { Error in energy prediction } \\
\text { of multi C-Si PV plant (\%) }\end{array}$} & \multicolumn{2}{|c|}{$\begin{array}{l}\text { Error in energy prediction } \\
\text { of CdTe PV plant (\%) }\end{array}$} \\
\hline & $\begin{array}{l}\text { Proposed } \\
\text { model }\end{array}$ & PVWATT & $\begin{array}{l}\text { Proposed } \\
\text { model }\end{array}$ & PVWATT \\
\hline January & 2.42 & -11.99 & 1.88 & 0.54 \\
\hline February & 0.50 & -2.4 & 4.49 & 2.04 \\
\hline March & -0.68 & 4.35 & 0.14 & 1.37 \\
\hline April & 1.89 & 6.66 & -0.95 & 1.85 \\
\hline May & -0.01 & 12.66 & -4.50 & 9.08 \\
\hline June & -1.51 & 22.21 & -0.95 & 12.32 \\
\hline July & -0.51 & 11.76 & -2.98 & 8.21 \\
\hline August & -0.74 & 3.02 & -5.52 & 12.41 \\
\hline September & -2.5 & 10.32 & 1.86 & -2.87 \\
\hline October & 1.89 & -8.01 & -0.97 & -5.87 \\
\hline November & 1.32 & -8.76 & 2.26 & 0.43 \\
\hline December & 0.79 & 1.38 & 2.25 & 8.26 \\
\hline
\end{tabular}

Pearson correlation coefficient ( $r$ ), Nash-Sutcliffe coefficient $(\mathrm{E})$ are presented to indicate the accuracy of the proposed energy prediction model.

All types of error coefficients were calculated and compared with PVWATT for establishment of the proposed model. The results are tabulated in Table 7.

\section{Discussion}

Figure $15 \mathrm{a}$ and $\mathrm{b}$ are presenting that the proposed model is in better co-relation with the actual energy generation of the power plant than the predicted energy generation of PVWATT. Regression co-efficient between the energy prediction of proposed model and actual output is 0.9516 , whereas the same in only 0.44 using PVWATT for Multi C-Si based PV power plant.

Regression co-efficient between the energy prediction of proposed model and actual output of CdTe based PV power plant is 0.97 as shown in Fig. 16a. The same in only 0.37 using PVWATT for the same power plant as shown in Fig. 16b. So proposed model is in better confidence than the model used in PVWATT in predicting the energy output for hot and dry climatic condition considering both Multi $\mathrm{C}-\mathrm{Si}$ and $\mathrm{CdTe}$ based PV power plant.

Table 6 depicts that the prediction in energy generation is much closer from proposed model than PVWATT in the months January, March, April, May, June, July, September, October and November for CdTe PV plant. $\%$ error in energy prediction for CdTe technology in proposed model varies from 0.14 to $5.52 \%$ where as in PVWATT the same varies from 1.38 to $22.21 \%$. For CdTe based PV plant maximum energy prediction error through proposed model is found in the month of August with a value of $5.52 \%$ whereas the same is 
Table 7 Error co-efficient comparison table

\begin{tabular}{llllll}
\hline Parameters & \multicolumn{2}{l}{ Multi C-Si } & & \multicolumn{2}{l}{ CdTe } \\
\cline { 2 - 3 } & Proposed model & PVWATT & & Proposed model & PVWATT \\
\hline RMSE & $10,159.4 \mathrm{kWh}$ & $49,414.62 \mathrm{kWh}$ & & $21,303.65 \mathrm{kWh}$ & $81,925.57 \mathrm{kWh}$ \\
NRMSE & 0.062 & 0.302 & & 0.087 & 0.334 \\
C $\mathrm{V}$ RMSE & 0.014 & 0.070 & & 0.028 & 0.109 \\
Nash-Sutcliffe coefficient (E) & 0.944 & -0.313 & & 0.949 & 0.243 \\
Coefficient of determination $\left(\mathrm{r}^{2}\right)$ & 0.952 & 0.444 & & 0.968 & 0.366 \\
\hline
\end{tabular}

maximum in the month of June using PVWATT software. For CdTe PV plant error in the prediction of annual energy generation is $0.07 \%$ and $4.52 \%$ using proposed model and PVWATT respectively.

Table 6 indicate that predicted energy generation in the months of February, March, May, June, July, August, September, October and December through proposed model is much closer to the actual energy generation from the Multi C-Si PV plant compared to the same from PVWATT software. Maximum error in prediction of monthly energy generation is observed as $2.42 \%$ in the month of January for Multi C-Si PV plant using proposed model, the same is $12.41 \%$ in the month of August using PVWATT. For Multi C-Si PV plant error in the prediction of annual energy generation is $0.01 \%$ and $4.2 \%$ using proposed model and PVWATT respectively.

RMSE, NRMSE, $C_{v}$ E and $r^{2}$ all the error prediction related co-efficients for the proposed model and PVWATT associated with the Multi C-Si and CdTe based PV plants are tabulated in Table 7. It is very clear that all the error predicting co-efficients are indicating the proposed model is giving better performance than the PVWATT in hot and dry climatic zone of India.

The results conclude that proposed model is simple and better deceive method than other available most recent tools. Because PVWATT is the most recent energy prediction tool and this software consider day-time temperature, whereas all other software uses over-all day average temperature from NASA Surface Energy and Solar Resource. So except PVWATT all other tools are already suffering from the problem of over-estimation. Comparatively overestimation in prediction of energy generation is less in case of PVWATT than other software. The study indicates that the prediction of energy generation using proposed model is less erroneous than PVWATT.

\section{Conclusion}

In this paper a newly proposed model is used to predict the energy generation from PV plants. To validate the decisiveness of proposed model, the actual energy generation of two PV plants based on two different PV technologies located in hot and dry climatic zone are compared with the predicted energy generation using proposed model. Actual energy generation is also compared with the most modern and accurate energy prediction tool PVWATT. Finding of the study are concluded as:

- For Multi C-Si based PV power plant situated in hot and dry climatic zone, regression co-efficient between the energy prediction of the proposed model and actual output is 0.9516 , whereas the same in 0.44 using PVWATT.

- In CdTe based PV power plant situated in hot and dry climatic zone, predicted energy generation using proposed model is in $97 \%$ confidence with the actual output of the plant where as same is $37 \%$ using PVWATT.

- For Multi C-Si PV plant error in prediction of monthly energy generation using proposed model and PVWATT varies from $0.01-2.42 \%$ to $0.43-12.41 \%$ respectively.

- Error in the prediction of annual energy generation for Multi C-Si PV plant is $0.01 \%$ and $4.2 \%$ using proposed model and PVWATT respectively.

- Error in the prediction of energy generation for $\mathrm{CdTe}$ technology using proposed model varies from 0.14 to $5.52 \%$ where as through PVWATT the same varies from 1.38 to $22.21 \%$.

- For CdTe PV plant error in the prediction of annual energy generation is $0.07 \%$ and $4.52 \%$ using proposed model and PVWATT respectively.

- Proposed model is simple and better deceive method than PVWATT.

Analysis shows that $\mathrm{CdTe}$ technology performs better than Multi C-Si technology in Hot and Dry climatic conditions. Results conclude that prediction of energy generation using proposed model in hot and dry climatic condition is less erroneous than PVWATT. Proposed model is simple and user friendly method to predict the energy generation of PV plant based on different PV technology in hot and dry climate. This mathematical method is simpler and requires less input data. Proposed model is useful for people from energy industry, energy planners, engineers, city planners, and climate concern citizens. 
Acknowledgements The authors acknowledge the support of National Institute of Solar Energy, An Autonomous Institute of Ministry of New and Renewable Energy, Govt. of India, for giving the opportunity to access the laboratory facility in successful completion of the work.

\section{Compliance with ethical standards}

Conflict of interest On behalf of all authors, the corresponding author states that there is no conflict of interest.

\section{References}

1. Chenni R, Makhlouf M, Kerbache T, Bouzid A (2007) A detailed modeling method for photovoltaic cells. Energy 32(9):17241730. https://doi.org/10.1016/j.energy.2006.12.006

2. Kerekes T, Koutroulis E, Eyigün S, Teodorescu R, Katsanevakis $M$, Sera D (2011) A practical optimization method for designing large PV plants. In: ISIE 2011, 2011 IEEE international symposium in industrial electronics, Poland, 27-30 June 2011, pp 2051-2056

3. Chakraborty S, Sadhu P, Pal N (2014) A new approach towards ideal location selection for PV power plant in India. TELKOMNIKA Indones J Electr Eng 12(11):7681-7689

4. Chakraborty S, Sadhu P, Pal N (2015) Technical mapping of solar PV for ISM-an approach toward green campus. Energy Sci Eng 3(3):196-206

5. Durisch W, Tille D, Wörz A, Plapp W (2000) Characterisation of photovoltaic generators. Appl Energy 65(1-4):273-284

6. Huld T, Súri M, Dunlop E (2008) Geographical variation of the conversion efficiency of crystalline silicon photovoltaic modules in Europe. Prog Photovolt Res Appl 16(7):595-607

7. Nfah E, Ngundam J, Tchinda R (2007) Modelling of solar/diesel/ battery hybrid power systems for far-north Cameroon. Renew Energy 32(5):832-844

8. Sasitharanuwat A, Rakwichian W, Ketjoy N, Yammen S (2007) Performance evaluation of a $10 \mathrm{kWp}$ PV power system prototype for isolated building in Thailand. Renew Energy 32(8):1288-1300

9. Cao J, Lin X (2008) Study of hourly and daily solar irradiation forecast using diagonal recurrent wavelet neural networks. Energy Convers Manag 49(6):1396-1406

10. Cao S, Cao J (2005) Forecast of solar irradiance using recurrent neural networks combined with wavelet analysis. Appl Therm Eng 25(2-3):161-172

11. Goh T, Tan K (1977) Stochastic modeling and forecasting of solar radiation data. Sol Energy 19(6):755-757

12. Hocaoğlu F, Gerek Ö, Kurban M (2008) Hourly solar radiation forecasting using optimal coefficient 2-D linear filters and feedforward neural networks. Sol Energy 82(8):714-726

13. Hontoria L, Aguilera J, Zufiria P (2002) Generation of hourly irradiation synthetic series using the neural network multilayer perceptron. Sol Energy 72(5):441-446

14. Mellit A, Benghanem M, Kalogirou S (2006) An adaptive waveletnetwork model for forecasting daily total solar-radiation. Appl Energy 83(7):705-722
15. Mellit A, Kalogirou S, Shaari S, Salhi H, Hadj Arab A (2008) Methodology for predicting sequences of mean monthly clearness index and daily solar radiation data in remote areas: application for sizing a stand-alone PV system. Renew Energy 33(7):1570-1590

16. Reikard G (2009) Predicting solar radiation at high resolutions: a comparison of time series forecasts. Sol Energy 83(3):342-349

17. Sfetsos A, Coonick A (2000) Univariate and multivariate forecasting of hourly solar radiation with artificial intelligence techniques. Sol Energy 68(2):169-178

18. Coelho A, Castro R (2012) Sun tracking PV power plants: experimental validation of irradiance and power output prediction models. Int J Renew Energy Res 2(1):150-159

19. Celik A, Acikgoz N (2007) Modelling and experimental verification of the operating current of mono-crystalline photovoltaic modules using four- and five-parameter models. Appl Energy 84(1):1-15

20. Yang H, Lu L, Zhou W (2007) A novel optimization sizing model for hybrid solar-wind power generation system. Sol Energy 81(1):76-84. https://doi.org/10.1016/j.solener.2006.06.010

21. Chang $T$ (2009) Output energy of a photovoltaic module mounted on a single-axis tracking system. Appl Energy 86(10):2071-2078

22. De Soto W, Klein S, Beckman W (2006) Improvement and validation of a model for photovoltaic array performance. Sol Energy 80(1):78-88

23. Evans D (1981) Simplified method for predicting photovoltaic array output. Sol Energy 27(6):555-560

24. Hove T (2000) A method for predicting long-term average performance of photovoltaic systems. Renew Energy 21(2):207-229

25. Joyce A, Rodrigues C, Manso R (2001) Modelling a PV system. Renew Energy 22(1-3):275-280

26. Ashraf I, Chandra A (2004) Artificial neural network based models for forecasting electricity generation of grid connected solar PV power plant. Int J Glob Energy Issues 21(1/2):119

27. Sulaiman S, Rahman T, Musirin I (2009) Partial evolutionary ANN for output prediction of a grid-connected photovoltaic system. IJCEE 1:40-45

28. Ayompe L, Duffy A, McCormack S, Conlon M (2010) Validated real-time energy models for small-scale grid-connected PVsystems. Energy 35(10):4086-4091

29. Bilbao J, Román R, Yousif C, Mateos D, De Miguel A (2014) Total ozone column, water vapour and aerosols effects on erythemal and global solar irradiance in Marsaxlokk. Malta Atmos Environ 99:508-518

30. Nvvn.co.in (2015) NVVN Ltd. http://nvvn.co.in/. Accessed 1 Jun 2019

31. https://photovoltaic-software.com/principle-ressources/howcalculate-solar-energy-power-pv-systems. Accessed on $10 \mathrm{Mar}$ 2019

Publisher's Note Springer Nature remains neutral with regard to jurisdictional claims in published maps and institutional affiliations. 